\title{
In the Name of Harmony: The Erasure of Domestic Violence in China's Judicial
}

\author{
Mediation \\ International Journal of Law, Policy and the Family, No.1, 2013. \\ $\mathrm{X}$ in $\mathrm{He}$ \\ School of Law \\ City University of Hong Kong \\ lwxin@cityu.edu.hk \\ $\&$ \\ Kwai Hang $\mathrm{Ng}$ \\ Department of Sociology \\ University of California, San Diego \\ kwng@ucsd.edu
}

\begin{abstract}
:
Based on observations of court trials and extensive interviews with judges, this article explores how judicial mediation in China undermines the rights of the battered women in divorce cases. We find that even if the judges are able to establish that domestic violence is committed, it is often erased in the stage of judicial mediation. This is because judicial mediation inevitably focuses on settlement arrangements. Lingering reference to domestic abuse would simply invite new denials or refutations from the abuser. It thus risks ruining the mediation efforts made by the judge. Our findings raise important questions with regard to the compulsory practice of mediation in family cases in China. It also sheds light on hidden problems created by judicial mediation or conciliation in general.
\end{abstract}




\section{In the Name of Harmony: The Erasure of Domestic Violence in China's Judicial}

\section{Mediation}

Perhaps the most conspicuous development in the Chinese judicial reforms of the last decade is the return to judicial mediation. Since the second term of Xiao Yang, the former president of the Supreme People's Court (SPC), the Chinese court has once again emphasized mediation over adjudication. Official statistics shows that in 2010, more than $65 \%$ of civil cases were resolved through either mediation or its varied form (China Law Yearbook 2011),' and the rate has been increasing for the past eight years. A primary justification of such a return is that mediation will contribute to social harmony (Xu 2006a; Fan 2005), a paramount goal pursued by the ruling communist party. For example, Liming Wang (2009: 69-70), a renowned scholar and lawmaker, states in this way:

"Judicial mediation, as a combination of both ethics and laws, proves to be more acceptable to the parties, and the mediation agreements are more voluntarily performed. Thus, judicial mediation plays a positive role in resolving social conflicts and promoting social harmony."

Only a few scholars are critical on the practice. Minzner (2011) argues that overall judicial mediation will do harm to the long term build-up of rule of law in China, and some are skeptical of the overarching role of mediation in dispute resolution in China (Zhu 2010). There has also been a longstanding concern shared among scholars that in its attempt to attain settlement, judicial mediation as an exercise sacrifices legal rights litigants supposedly enjoy (Lubman 1999;

\footnotetext{
${ }^{1}$ In most situations, mediations and withdrawals are difficult to differentiate because a platintiff may withdraw her petition simply because a settlement has been reached. In official statistics, the case can be either categorized as one that is resolved by mediation or as withdrawal.
} 
Peerenboom 2002; Wu 2009). Important as the concern raised by these scholars is, their focus is confined to the long-term impact of mediation to the legal system of China. It is fair to say that few have analyzed the international processes between the judges and litigants in judicial mediation (the only exception may be $\mathrm{Wu} 2007)$. The lack of data on how mediation actually works, especially the new form of judicial mediation (He and $\mathrm{Ng} 2012$ manuscript) now prevalent in the Chinese legal system, means that little has been said about the present and immediate effects of the practice on the growing number of civil litigants who arrive at the doorsteps of the courthouses in China.

One of the fastest growing and socially most vulnerable groups of civil litigants is battered women who seek relief from the abuses done to them by their husbands. Domestic violence has become an increasingly serious problem in China. By some estimates, as high as 30 per cent of families in China have issues with domestic violence (Wexler 2003; Woo 2003). According to Wu (2007: 203), who reviewed 310 divorce cases from 1950-2004 from a county in southern China, almost in all of the cases the wives alleged being abused by the husbands. Drawing from ethnographic observations of the actual proceedings of judicial mediation and in-depth interviews with judges who preside over divorce trials, this article explores how judicial mediation undermines the rights of these battered women in divorce cases. We find that even when the judges have been able to find evidence of domestic violence, it is often underplayed or erased in judicial mediation. We refer to this omission as a form of "erasure," in ways similar to "the marginalization of domestic violence” found by Greatbatch and Dingwall (1999) as well as Trinder et al (2010) in their study of divorce mediation sessions. But the erasure practice underlines the wider power discrepancies inherited in judicial mediation in China. As we will show, women plaintiffs are rendered as passive victims who simply want to get out of their marriage in Chinese-style judicial mediation. Our findings raise important questions with regard to the policies on China's family law 
procedures; in particular, it points to the inadequacies in safeguarding the human rights of women who suffered domestic violence. It also sheds light on the hidden problems created by a system that values conciliation and quick resolution over adjudication and the delivery of justice.

\section{Domestic Violence LAWS IN CHina}

While gender equality has long been hailed as a fundamental social goal by the Chinese communist regime, the term "domestic violence" did not appear in Chinese laws until 2001, the year when the marriage law was revised. In 2001, the SPC further issued a judicial interpretation of the new marriage law. Domestic violence is defined as behavior toward a member of the family that results in injurious consequences physically, emotionally, or in other ways by "beating, tying up, injuring, forcibly restricting one's personal freedom, or by other means” (Wang 2004: 182). Article 3 of the law prohibits domestic violence. Article 32 states that divorce shall be granted by court if domestic violence or, maltreatment and desertion of one family member by another, is found. For the purposes of this article, the most relevant part of the law is Article 46, which provides that the innocent party is entitled to damage compensation in divorces as a result of domestic violence. There are also some piecemeal local legislation and administrative orders that regulate the use of restraint orders. But the three articles mentioned above already make up the core of the domestic violence law in China at the national level. Activists and scholars have called for a separate and more comprehensive national law on domestic violence. However, at the time of this writing, it has not been placed on the agenda of the National People Congress (NPC), the highest legislative body of China. Scholars have commented that the existing stipulations on domestic violence are terse 
and, in fact, quite vague. That said, the revised marriage law does allow for recourse to civil litigation for battered women.

Historically, there have been many difficulties facing battered women who took their cases to courts. Law enforcement officers in China were not particularly concerned with domestic violence complaints (Liu 2001: 6-7; cited by Merry 2006: 149). They classified these complaints as "spousal quarrels" or "family trouble." Furthermore, in part because of the Confucian belief in social harmony and in part because of the Chinese reluctance to interfere the "family matters" of others, there was a general reluctance for family members, friends, coworkers, and relatives to testify against the violent husband in court serve as witnesses" (Xu 2006a; 2006b). "Even brothers and sisters of the abused woman may feel intervention inappropriate” (Liu 2001: 6-7; cited by Merry 2006: 149).

In cases where eye witnesses are either reluctant or unavailable to come forward to testify (and there were many), judges have been reluctant to address domestic violence in their rulings. Subject to heavy scrutiny from the upper-level courts, these judges do not want to issue any decisions without strong evidence. There are good reasons for judges to exercising cautions in this area of law, with self-preservation perhaps the biggest psychological driver. China's lower-level trial courts have been and still are consistently plagued by a high appeal rate of their judgments. A junior judge can be subject to disciplinary measures or other punishment when adjudicatory mistakes, which are not uncommon, are identified. For example, in 1999, about $50 \%$ of trial court judgments were appealed. Among these judgments, only about a quarter (26.6\%) of them were sustained (Zhong and Yu 2004: 428). According to the current evidence rule, if a victim cannot provide strong evidence (e.g., a medical certificate of the injuries suffered and/or police reports), she is not considered to have satisfied the burden of proof required for convicting an alleged 
violent husband. In these cases, most courts are left with no options but to disregard the existence of domestic violence (Huang 2010: 133-134).

But domestic violence has become an increasingly serious social problem in China, so much so that it has made itself into the official agenda and public discourse of the Chinese government. For example, in 2008, Sun Xiaomei, an NPC deputy and professor at the Chinese Women's College, said: "Domestic violence is a social phenomenon that crosses all social strata and is becoming more and more common. There is an urgent need for legislation” (Jian 2008). In 2010, the state-backed All-China Women's Federation (ACWF), the largest women organization in China, announced that its branches nationwide received 52,000 petitions from women who suffered from domestic violence (China Daily 2012). It further declared that "domestic violence poses a severe threat to women's rights in China” (Xinhua 2009).

In response to the newfound attention to addressing domestic violence, Chinese judges are now taking steps to protecting women from domestic violence. The court we conducted our study, for example, was among one of the courts in ten provinces that participated in a national pilot program for issuing protection orders to victims of domestic violence. The order, models on similar orders (protection from abuse orders, restraining orders) commonly used in AngloAmerican law, forbids a husband from coming within 100 meters of the wife's home. It also forbids the husband from harassing, frightening, hitting or following Chen, her relatives and friends. If he violates the order, the court will also detain or impose a fine on him (China Daily 2002).

More importantly, judges are more proactive in proving the existence of domestic violence, usually by getting the abuser to confess. The biggest structural hurdle, as the rest of this article will 
demonstrate, is the conflicting demands created by the in-trial judicial mediation procedure in resolving family disputes, including divorce petitions.

\section{METHODOLOGY}

The episodes analyzed in this article are taken from trials that we attended in December 2011 at a district court in City Z in Southern China. Located at the heart of the Pearl River Delta, the most affluent region of the country, the city's GDP per capita reached USD 11,000 in 2010. It has thus attracted a large number of migrant workers, who come from the hinterland areas of the country for a better living. Of the 800,000 population in the jurisdiction of the trial court in which our sampled trials were heard, a total 300,000 of them were registered migrants. While the official language is Mandarin, a significant portion of the population speak Cantonese as their everyday language.

Our data come from three different sources. The first, and the main source of our data, are our direct observations of divorce trials in action. Gaining access to the court through personal connection, we observed the trials of a designated family court for a period that lasted about a month. The designated family court was made up of three judges, two regular women judges and a male judge seconded from nearby county court to help clear the accumulating caseloads. Comparing to common law trials, which can last for weeks, even months, civil trials in China generally proceed at a crisp pace. It typically takes one court session, i.e., a half day, for a hearing to complete. Some trials are shorter than others. We saw trials that were quickly wrapped up in around ten minutes (e.g., when the defendant did not show up). That said, a typical hearing takes up about one to two hours. We observed about twenty hearings during the period of our study, of 
which about a third allegedly involved domestic violence.

Tape recording of proceedings is not allowed in the courtrooms of China. During our fieldwork, we relied mostly on our written notes. The relative short sessions made extensive note taking a less exhausting exercise. Toward the end of our fieldwork, the local judiciary kindly agreed to make available to us copies of official court transcripts of a number of trial sessions we had attended. The transcripts were prepared by court clerks who worked with judges. The transcripts used below are based on our own written notes and the official transcripts. ${ }^{2}$

The second part of our data is made up of our interviews with the judges. We interviewed the judges who presided over the trials we observed. We were also able to interview other judges who had handled divorce hearings in their career, as well as court administrators and researchers who could provide us with information about the new judicial initiatives to address domestic violence. The interviews provided us with useful background information about why judges asked certain questions and what evidence they considered would constitute the basis of the court decision. We asked them, among other matters related to China's civil justice system, of their views about the existing practices of in-trial mediation. In some cases, we discussed with them certain specific trials we observed. As a group, they were candid and open about their opinions on the performance of the parties, the weight they gave to certain evidence, and their rationale for the decisions they reached. The interviews lasted from between thirty to ninety minutes.

Our field site is a compelling setting in which to study how domestic violence is handled as a legal problem in China. As mentioned, the county court we studied was among one of the courts in the national pilot program to reinforce protection for women against domestic violence. We make

\footnotetext{
${ }^{2}$ In the interest of space, we reproduce only the English translation of the transcripts. The transcripts in the original Chinese (Mandarin and Cantonese) are on file with the authors.
} 
further efforts to validate the generality of our findings. For our third data source, we interviewed, mostly by phone, experienced family court judges in different parts of China, including the provinces of Jiangsu, Guangxi, Zhejiang, and Shaanxi. All these findings are integrated with secondary data collected by others on this topic (e.g., Wu 2007; Huang 2010).

\section{Judicial Mediation}

For a country as populous and fast-changing as China, its civil procedure is highly unified and homogeneous. The same set of procedures applies across different parts of the country. If one attends a civil trial in China today, the presiding judge will announce at the beginning of the process that a civil trial consists of four stages: court investigation, court discussion, court mediation, and decision announcement. Each of the different stages is part of the civil trial process. The judge thus serves as both adjudicator and mediator at different stages of the trial. In most trials, mediation takes place right after the court investigation and discussion, within the same court session (usually lasting a morning or an afternoon).

The current Civil Procedural Law stipulates that the court may or may not conduct mediation after court discussion. But for family cases, mediation remains a compulsory procedure that requires litigant to participate. This is primarily because, as mentioned earlier, mediation has long been regarded as a way to mitigate family conflicts and contribute to family and social harmony. This emphasis has been further intensified since 2004, halfway through the Westernstyle civil procedural reforms initiated by the former SPC president Xiao Yang. The party and higher-up believed that the Western style of judicial reforms had gone too far: they believed that 
the reformed judiciary did not really resolve disputes, even though many cases could be said to have been adjudicated with a higher degree of procedural fairness. They also believed that the skyrocketing number of petitions (shangfang) was a result of the incompetency of the judiciary. The policy response is for the judiciary to renew its reliance on the role of mediation $(\mathrm{Fu}$ and Cullen 2011; Wayne and Xiong 2011). Accordingly, courts have been revising their incentive mechanisms to encourage judicial mediation. ${ }^{3}$ As a result, many courts, including the court that we visited, have been requiring their judges to settle, through mediation, a certain percentage of cases they handle. The ratio of cases being closed with a mediated settlement has become a criterion to assess a judge's performance. There is also competition among courts for higher overall mediation rate. Henan High Court, for instance, even claim that their goal is to achieve zero adjudication, meaning that all the cases received by the courts are resolved with mediated settlements (Peng 2011).

Pressure from senior court administrators aside, some judges do prefer mediation to adjudication: enforcement becomes less of a concern when parties agree to settle as a result of mediation; there is no risk for a decision of being appealed against since the result is agreed upon by the parties; judges are spared the effort of writing a judgment. Of course, many judges also believe that both parties are better off with a settlement. All these considerations compel judges to adopt a heavy-handed approach to litigants at in-court mediation sessions. As a consequence, the percentage of civil cases resolved through mediation in China has since increased, while the rate of adjudication has decreased from 43\% in 2002 to $31 \%$ in 2010 (China Law Yearbook 2011).

\section{EVIDENCE: THE FOCUS OF COURT INVESTIGATION}

\footnotetext{
${ }^{3}$ The SPC Provisions on Court's Civil Mediation Work in 2004 provide that "all cases that can be mediated should be mediated."
} 
It is under this context that we should understand the behavior patterns of the judges in divorce hearings. Trials in China are judge-centered. Until recently, it has been the judge alone who owned fact-finding power. But the courts nowadays rarely collect evidence outside the courtroom (He 2009; Huang 2010; Woo 2003). They are many reasons why judges today do not want to initiate out-court investigation of their own, some ideological and some practical. Ideologically, China's courts are shifting to a judicial philosophy of dangshiren zhuyi, meaning litigant's choice. Courts have now gradually passed the responsibility of proving a case to litigants. Practically, there are many reasons why judges want to avoid out-court investigation - the ever increasing caseloads received by courts, limited human and financial resources, the pressure to boost efficiency by closing a case within a relative short timeframe. Judges now engage in a limited form of cross-examination aimed to obtain oral testimony that can be used to justify a decision. This kind of judge-initiated questioning thus becomes an inexpensive substitute for the previously labor-intensive court investigation. In other words, the court investigation stage offers them an important opportunity to collect evidence which forms the basis of their later adjudicative decisions, if a settlement cannot be reached. The evidence on which their potential adjudicative decisions are based must be strong enough to safeguard the judges from any potential liabilities for wrongfully decided cases.

When domestic violence is alleged, it is the responsibility of the judge to take proofs to validate the claims. An allegation of domestic violence are usually denied or refuted by the husband. But a judge, for the purpose of collecting evidence, is willing to confront the litigants in this process. The excerpt below is taken from a case we observed where domestic violence is alleged by the wife as the ground for divorce:

[Judge] On the very early morning of the $25^{\text {th }}$ of September, 2011, is it true that you hit her? 
[Defendant] (pause) What do you mean by hitting? I don't know. Hitting means...

[Judge] Didn't I just show this to you? She said you used your fists, and a solid object, a folding chair that was, to hit her back. She was at pains. Then she called the police. The police gave you a warning when they arrived.

[Defendant] No, no, no, I didn't hit her. At the time, we were fighting with each other.

[Plaintiff] The police then...

[Defendant] We were fighting with each other! We were fighting with each other!

[Judge] Fighting with each other? But did you hit her back with that folding chair?

[Defendant] Just to scare her.

[Judge] Was her back hurt?

[Defendant] This I'm not sure.

[Judge] (turning to the court clerk) Scared her. Then I asked him if the plaintiff's back was hurt, he said he didn’t know.

[Judge] (turning to the defendant) Afterwards, the police were at your home, right?

[Defendant] Yes, at my home.

[Judge] What did the police do when they got to your home?

[Defendant] They asked a few questions; and then told us not to argue again. They asked us not to argue about little things. They kept a record of our names and then they left. 
[Judge] So on that day, did you hit her or not?

[Defendant] I did not hit her. We were fighting with each other.

This is a disturbing, and yet unfortunately, not too uncommon case that one finds in the family courts of China today. During the trial, the plaintiff, a lowly-educated "rural wife" is emotional. She claims that her husband has beaten her and their son for over 600 times during the course of their marriage. She struggles to hold her composure. She testifies with a wailing voice, recounting the violence inflicted on her. The air was heavy inside the courtroom. It is a difficult experience for the audience as well. As shown in the above conversation between the husband and the judge, the husband denies he used violence. He describes what happened as duida in Chinese, meaning fighting with each other. The judge tries to see if there is any police report which might constitute strong evidence against the defendant. But apparently the police just made a routine visit and then left without investigating the incident in detail. Without a police investigation, the case turns on the evidence the wife produces through her testimony. Apparently, the judge is of the view that the oral testimony of the wife alone, does not carry enough weight to warrant a her to factor in domestic violence in her decision on the divorce petition. In a bid to draw out more damning details from the man, the judge launches a series of probing question to get the defendant to acknowledge the use of violence:

[Judge] Have you ever choked her?

[Defendant] As for choking, I did that when she hit me; I feared that she would hit me back. [Judge] (turning to the clerk) I asked him if he ever choked the plaintiff. He said he did, for fear that she hit back. (turning to the defendant) How long did you choke her? 
[Defendant] I guess it was about five seconds. Four or five seconds.

[Judge] When you choked the plaintiff, what was her reaction?

[Defendant] She hit me with her hands, or sometimes kicked me.

[Judge] And have ever choked your son?

[Defendant] I did. Yes, yes.

[Judge] (turning to the clerk) The plaintiff resisted. Choked his son. (turning to the defendant)

When you choked her, was she not able to breathe?

[Defendant] No

[Judge] How many times did you choke your son?

[Defendant] Probably once or twice.

[Judge] What about the plaintiff?

[Judge] It's about the same.

[Plaintiff] Tell the truth.

[Defendant] I told the truth.

[Plaintiff] Tell the truth about what you did to our son. Tell the truth about what you did to me. Don’t say it was just twice! Don’t say things that contradict your conscience.

[Defendant] We lived together for twenty-odd years. How much have I done for you? What have you done for me? 
[Plaintiff] You should tell the judge.

[Judge] How many times have you choked the plaintiff?

\section{[Defendant] Twice.}

This excerpt shows how the judge tries to prove the wife's domestic violence claim through a form of cross-examination commonly seen in the civil courts of common law jurisdictions. In the interviews with us right after the court trial, she said choking is serious - it is life-threatening; and once a husband did it to his wife, he tended to repeat it again; and later incidents of choking often perpetuate even greater violence against the wife. From the judge's perspective, choking, if admitted or proven, constitutes a piece of strong evidence for domestic violence claims. To make the case beyond reproach, the judge asks the husband how many times he choked his wife and his son. The judge is also meticulous in asking how long the man choked his wife and son during these incidents. The judge is doubtful if the man told the truth. Upon hearing his testimony, his abused wife is emotional and asks him not to contradict his conscience. The man tries to downplay the severity of these choking incidents - he said they happened once or twice; and each time they lasted for just four, five seconds; and above all, they happened not as brunt violence against his wife, but as his way to defend himself in a fight with a woman who was trying to hit him hard. As the judge told us afterwards, from the perspective of law, what the man admitted was enough to prove domestic violence. The judge is so careful that more than once she has instructed her court clerk what to put down on the court records, which will be signed by both litigants, in ways that capture the gravity of the man's testimony. "He admitted he choked her; and he also choked his son." The judge carefully rephrased the language to align the man's testimony with the relevant facts that 
constitute the legal definition of domestic violence, an important technique as identified by Mather and Yngvesson (1980-1981).

The judge does not stop here. She further inquires another incident in which the wife claims that the husband took her away from work and threatened to tie her up and abuse her.

The judge, once again, tries to retrieve the details of the incident by questioning the defendant.

[Defendant] I went to her unit to see her then. At the time, she had left home for seven days. I went to her unit to pull her out from her work because I wanted her to come back home. Come back home; whether we were to divorce or stay together, we could discuss later. Come back home first. But she was dragging out the discussion. She said this and she said that. I was angry. I faked hitting her. But it happened at the work unit. I didn’t know who reported to the police. She was away from home for seven days then.

[Judge] You said you pulled her out from her work, right? What next?

[Defendant] Yes, we took the taxi to get home.

[Judge] Took the taxi. And then you dragged her back home?

[Defendant] I didn’t drag her back home. She left her work to her colleagues, then returned home. And then I followed her back home. But then we went back and forth with several taxis. Back and forth. It was a hassle.

In our interview with her, the judge said although the wife claimed that there were witnesses and video recordings, she was unsure if the additional oral and material evidence would be made 
available to the court. But the questions confronting the husband have secured sufficient evidence. For another instance, the judge got from the defendant to admit that the couple changed taxis several times back and forth on the day he pulled his wife from her workplace. The judge said the fact that the couple changed taxis was another piece of good evidence to corroborate the domestic violence claims. In her opinion, it is difficult to explain why the couple had to change taxis and went back and forth on the trip. The judge argued that this strongly suggested that the wife was resisting her husband's attempt to carry her away from work and physical violence was likely involved. While the judge did not undertake a full-fledged cross-examination, she sought to, within the limited time available in a Chinese civil trial (as mentioned, which normally lasted for a half day in a busy court like the court we studied in City Z), built a case through oral testimonies.

The analysis above identifies several points, which are also supported by the data we gathered from the other cases we observed. First, contrary to the common stereotype that many lowly educated women in China are too acquiescent to defy their husbands in public, the women who appeared in the trials we observed were not intimidated to tell the judge that they had been victimized by their abusive husbands. Indeed, some of them were eager to tell the judge, for legal as well as cathartic reasons. Many are prepared to address domestic violence issues directly in court. In this case, the woman plaintiff addresses in detail the severity of violence against her. Our data seem to suggest that once women have decided to undertake legal action, they have little difficulty in overcoming the stigma of talking "family matters" in public. In our interviews with the judges, they said they believed some women plaintiffs thought strategically. Some women believed that domestic violence might help them obtain a quick divorce decision; some women believed that a violent husband would lose child custody; others believed it provided leverage for getting a favorable division of marital property. But judges acknowledged that some women simply wanted 
to shame their husbands, or relieve their fear and frustration in public. For these various reasons, women plaintiffs often raise the issue of domestic violence during the court investigation stage of a trial. The problem facing these women was that they did not know how to, as it were, produce evidence and give testimonies in court. Many of them are not represented by lawyers. Even when represented, they usually do not have the required documents (police report, medical records, or their own written statements made at the time when they were abused) necessary for the purposes of the law.

Second, as a result of the virtual abandonment of out-trial court investigations, the in-trial court investigation stage is becoming more important for judges to prove domestic violence. It remains the discretion of a judge whether she wants to "cross-examine" an alleged abuser or not; but for those judges who do, it is clear that in-trial court investigation has become a judge's main weapon to prove or disprove unresolved allegations of domestic violence.

Third, the role of a judge depends heavily on the person's skills and willingness to collect evidence. As shown in the above case, for example, the judge goes beyond the neutral role of assessing evidence, and plays an active role in collecting evidence. This is within the range of the Chinese procedural law, but it is also equally lawful had the judge simply dismissed the domestic violence claim on the ground that the plaintiff was not able to produce evidence herself. In this case, the man gave testimony that the judge considered sufficient for proving domestic violence. In taking a proactive role, the judge's effort to collect evidence in the court investigation stage offers a chance in protecting the domestic abuse victims.

A proven domestic violence allegation is consequential for the plaintiff and her family. Not only is it more likely for the plaintiff to get a favorable divorce settlement and win the child custody 
battle, she also receives protection by the court from her husband's future abuses. For the court that we study, which is one of the courts involved in the aforementioned national pilot program, it can issue a protection order to remove the husband from his home and prevent him from seeing his son or even talking to his wife. Unfortunately, the evidence collected in this stage, as we will show, will be erased in the court mediation stage when the focus then is to work out a solution, which is incompatible with any confrontation.

\section{SOlution: THE Focus OF COURT Mediation}

The role of the judge in the court investigation stage contrasts greatly with her role in the mediation stage that immediately follows. From the perspective of the judge, while the focus of court investigation is to collect evidence, the focus of mediation switches to achieving resolution:

the goal of the judge here is to find a middle ground that both litigating parties would agree upon. If the key question that dominates the investigation stage is "Did you commit what she accused you of doing?", the key question at the mediation stage is "Do you accept this proposed solution?"

In the divorce case we detailed in the previous section, there was too much hatred between the couple for any meaningful mediation effort. Even though, for reasons unknown to us, the woman later withdrew her case, the judge said in her later interview with us that she was prepared to address the issue of domestic violence in that case. Other cases are not as clear-cut. Of the other four cases where domestic violence was alleged, the issue was ignored and discounted because these cases had gone through the intensive procedure of in-court mediation. Many couples are willing to go through judge-directed mediation, not so much because they want to stay together again, but more because there is still a lot to bargain with their estranged spouse. For many uncontested divorce cases, there is little doubt left that divorce would be the eventual outcome: 
when a divorce petition is filed, the petitioner is usually determined to divorce. Under the current de facto no-fault rule governing divorce (Huang 2010; Davis 2010), the petitioner would get his or her wish fulfilled sooner or later. Indeed, as He (2009) finds in another court in Guangdong province, the number of divorce petitions approved is three times as much as those petitions denied. It is, quite simply, only a matter of time. The mediation session focuses on the partition of child custody and marital property. In so doing, it is almost inevitable that the question about domestic violence, which is almost invariably denied by the abuser, is erased. As shown, when domestic violence is examined during the court investigation stage, the litigation parties are confrontational. It is common for parties to trade accusations, curses, and denials. If the judge still focuses on the issues of the investigation stage, including domestic violence, lingering investigations would undermine the reconciliatory tone required to facilitate successful settlement. It is for this reason that erasure is a consequence of mediation.

That is exactly what happened in another case we observed in which domestic violence was alleged but was not subsequently followed up in the mediation stage of the trial. It is a divorce case in which the couple have been separating from some years and the husband is now living with another woman. There were no disputes that the husband has committed domestic violence and had extra-marital affairs: the wife provided police reports and pictures of bruises. The two agree to divorce; their disputes are mainly about how to divide up their communal unit and their responsibilities towards their son. The 13-year-old son has been living with his mother. As in many other divorce cases, the estranging husband and wife were fighting over various accusations in the court investigation process. The atmosphere was tense and confrontational in the first hour of the trial. As if she were intended to prevent the confrontation from escalating, the judge quickly moved to mediation without formally announcing that the investigation and discussion stages were over. In 
fact, she did not formally ask the two parties if they would agree to participate in mediation, as most judges would ask at the end of the court discussion. She started working on a settlement right away she knew the two sides had no intention to linger on with their failing marriage. After about 30 minutes of negotiations back and forth with the couple, the judge managed to work out a number that indicated the sum of money the wife would get in renouncing her half of the property. Eventually the judge persuaded the two sides to agree to adopt the number $(200,000$ yuan) as the basis of their settlement. Beside the disagreement over dividing the communal property, the couple also disagree over child support. The plaintiff is willing to pay 500 yuan per month, but his wife the defendant wants more. She asks for a monthly child support of 800 yuan. The judge quickly decides that she is trying to get the two sides to settle on 600 yuan. To the judge's surprise, the plaintiff refuses to raise his offer to make up the 100 yuan (approximately $\$ 15$ per month) difference. This put the judge in a tough spot. She has already let both parties know a compromised figure that she found to be acceptable, knocking down the wife's request of 800 yuan by 200 yuan. She thought this could get the deal done. But the plaintiff's recalcitrance created an impasse.

In order to get the deal done, as we detailed elsewhere (He and $\mathrm{Ng} 2012$ manuscript), the judge marshaled all sorts of resources available to convince the man. She mentioned the money was used to support his son, not a stranger; she also mentioned that as his son is already 13 years old, the overall amount of support is not a big sum because the man is only responsible for supporting the child till the age of 18 ; she even challenged the truthfulness of the man's salary, which according to the law, is used as the basis for calculating the amount of child support; she preached to the man that it was his duty as a father to support his son. What is most revealing for our purpose here is that the judge never mentioned a word about domestic violence. Should not 
the man be held responsible for his abusive behavior, as stipulated by Article 46 of the amended Marriage Law? Is not it an excellent leverage to force the man to agree to raise his child support by 100 yuan?

In another case documented by Wu (2007: 277-281), the wife repeatedly raised the issue of domestic violence and presented police reports that she suffered light injury. The husband denied the link between the injury and his behavior. Below is an excerpt of a private conversation between the judge and the wife during mediation in the absence of her husband and her family.

Wife: "I dared not disclose anything to anyone outside of the family. Sometimes I was all beat up and bruised. But when other people asked me how I got my bruises, I just told that was because I fell. I dared not even tell the truth to my own parents.”

Judge: "If both sides can reach a settlement, we will ask you to sign the mediation agreement. If not, the court will adjudicate. We will try our best. The mediation ends here.”

This conversation shows that the judge did not even take up the topic of domestic violence raised by the wife. In mediation, as the term suggests, the two parties tries to arrive voluntarily at a resolution. The judge, who now acts as a mediator, removes the adjudicatory frame that looks for fault and denounces wrongful behaviors. The rights-based focus prevailed at the investigation of domestic violence is now superseded by the need-based focus of mediation (Cobb 1997). The judge, in order to achieve a mediated result, was extremely careful in maintaining a less antagonistic atmosphere. Further allegations of domestic abuse would simply invite more denials or refutations from the man and compromise her efforts to mediate. In other words, to get a mediation result, the judge has to exclude blame from her discourse. 
Evolving from court investigation to court mediation thus involves a process called by Cobb (1997) as “transformation.” In court investigation stage, the rules are legal, focusing on rights and obligations, based on the availability of evidence; but in court mediation stage, the rules are mediatory, focusing on needs. In the mediation session, the mediatory rules soon gain dominance and expand its authority and jurisdiction, crowding out concerns for legal rights and moral blaming. Cobb (1997: 413) points out,

"[t]he goal of mediation is to reach agreements, to meet the needs of individuals, not instantiate a moral code. In fact, mediation is designed to subsume moral differences by colonizing competing moralities: There is no 'right' way to live, except that morality which permits and enforces relativism.”

Also, as demonstrated by Fineman (1988) in her analysis of custody mediation, the rights of parents are collapsed into the needs of the children through the discourse fostered by the "best interest" doctrine. Because the goal of mediation is to reach agreements, it has to meet the needs of the individuals and the overall discourse is pragmatic (He and $\mathrm{Ng} 2013$ forthcoming). Indeed, as Silbey and Sarat (1989) note, mediation legitimates itself as a practice by distinguishing between rights and needs: rights discourse is suitable for formal settings in which hierarchy and power are at issue; needs discourse is suitable for mediation where it is not power but participation that is at issue. The mediation session offers a setting for both disputants, as co-participants with equal social and legal status in the resolution of conflict. In this process any violence, including domestic one and especially those are still subject to dispute because of a lack of evidence and the vague legal stipulation, has to make room or relational and economic security and thus be sidelined to a level of disappearing. 


\section{CONCLUSIONS AND IMPLICATIONS}

Western researchers have found that in community-based mediation sessions, domestic violence is often domesticated (Lerman 1984; Rifkin 1989; Sarat and Kearns 1991; Cobb 1997;

Greatbatch and Dingwall 1999). By “marginalization," Greatbatch and Dingwall (1999: 187) means that violence reports are "ignored or minimized", and events are framed as "relational as opposed to criminal." The situation is no better in court-based mediation programs. As Trinder et al (2009)'s study of the English system found out, family justice professionals continued to marginalize allegations of domestic violence, some even turned punitive in cases where women insisted on the issue. This article shows that in China, despite the fact that the issue of domestic violence is raised, discussed, and even established in the court investigation process, it is eventually forgotten, often unnoticed in the court's final mediation session. If anything, the situation in China is more serious, for two reasons. First, since it is the judge who mediates in China, she is entitled to adopt a much more interventionist approach to sideline allegations of domestic violence. Compared to what is discussed as marginalization (Greatbatch and Dingwall 1999) or domestication (Cobb 1997), the erasure of domestic violence in China is more coercive; this is in part due to the obvious power gap between the judge and the disputants. Judges are aggressive and proactive in setting a mediatory tone, compared to the more subtle handling by mediators in community mediations. Second, from the perspective of the victims, the process is somewhat deceptive. This is because of the presence of judicial mediation within a framework of adjudication (He and Ng 2012 manuscript). The victims who choose to settle the case might think they have sought a legal redress, but in fact they have unknowingly surrendered their legal rights in agreeing to a mediated deal. Moreover, in going through judicial mediation, they have already exhausted all their legal remedies and there are no other recourses. The Chinese government has finally come to 
realize the seriousness of domestic violence as a social issue. However, its judicial infrastructure, caught between the conflicting goals of achieving efficiency and protecting the socially vulnerable, is structurally incapable of addressing the issue in a systematic and comprehensive way.

During the past decade, the use of mediation to resolve civil disputes, including divorce petitions and other family disputes, has been on a steady rise in China. Official statistics shows that in 2010 , more than $65 \%$ of civil cases were resolved through either mediation or its varied form. What we described here is part of a bigger trend. We discussed this wider phenomenon and its implications to the rule of law in China elsewhere (He and $\mathrm{Ng} 2012$ manuscript). Here, our findings suggested that family violence factored into a judge's decision only in the most blatant cases. As mentioned, of the about twenty cases we observed, the case we analyzed above was the only one we observed where the judge brought up and addressed the issue of domestic violence in her judgment. For the other handful of cases in which allegation of domestic violence was made, the issue was marginalized and overlooked in the process of mediation. This phenomenon is also consistent with the findings from other regions (Wu 2007). All these show how substantive concern over domestic violence is sidestepped and superseded by the administrative preference of mediation over adjudication for the courts. Furthermore, the fact that the court we study participated in China's national pilot program for protecting women against domestic violence seems to suggest that other courts might bestow even lesser attention to the issue.

Our findings thus seriously challenge the practice of judicial mediation in China and particularly the arrangement of civil procedure on family cases. In China, mediation is a compulsory requirement for family law-related cases, whether or not the litigants want to participate in the process. The compulsory requirement is justified by the belief that mediation alleviates creates a less antagonistic environment that reduces further disputes and favors solution. It also 
facilitates the disputants to consider the best interests of the most vulnerable party, i.e., children of divorced couples. More mediation and less litigation is also said to promote social stability. This justification seems so powerful that they are seldom questioned or challenged in the context of China. This study reveals a significant problem of the current practice: victims of domestic violence are paying a heavy price for what is seemingly a well-intended procedural arrangement. While it is unclear whether judicial mediation indeed realizes its goals, it is clear that the rights of victims of domestic violence are compromised. To avoid such undesirable consequences, the current compulsory requirement shall be abandoned. Furthermore, in line with what has been suggested by some scholars, a certain screening system can be introduced to screen cases involving family violence from mediation (Hester et al 1997; Trinder et al 2010). At the very minimum, the victims of domestic violence going through the mediation process shall be formally warned of such a consequence.

By the same token, policy makers shall also seriously consider whether judicial mediation shall be allowed in other types of cases in which violence is involved. In the meantime, there is a tendency in China's judicial practice to reconcile the attackers and victims in personal tort and even criminal cases (Chen 2006). Whether or not the issue of violence is also erased in mediations of other types of cases awaits further research. For violated women seeking divorce, this study cautions strongly against any congratulatory view of mediation as a cure-all social panacea. 


\section{References:}

Chen, Ruihua. 2006. “Private Cooperation in Criminal Procedure," (刑事诉讼的私力合作模式), Zhongguo faxue [China Legal Science]. 5, 15-31.

China Daily. 2012. "Court tries woman protection program" at http://www.chinadaily.com.cn/china/2012-02/23/content_14678191.htm, last visited June 1, 2012.

China Law Yearbooks. 2011. China Law Yearbooks. Beijing: China Law Yearbooks Press [中国法 律年鉴社].

Cobb, Sara. 1997. "The Domestication of Violence in Mediation," Law and Society Review 31(3): 397-438.

Fan, Yu. 2005. "Guanyu fayuan tiaojie de shizheng yanjiu [Empirical Analysis to Juridical Mediation].” In Falü chengxu yunzuo de shizheng fenxi [An Empirical Analysis to Practice of Legal Procedures], edited by Wang Yaxin. Beijing: China University of Political Science and Law.

Fineman, Martha L. 1998. "Dominant Discourse, Professional Language and Legal Changes in Child Custody Decision-Making,” 101 Harvard Law Review 727-74.

Fu, Hualing and Cullen, Richard. 2011. "From Mediatory to Adjudicatory Justice: The Limits of Civil Justice Reform in China.” In Chinese Justice: Civil Dispute Resolution in Contemporary China, 25-57, edited by Margaret Y.K. Woo, and Mary E. Gallagher. New York: Cambridge University Press.

Greatbatch, David \& Robert Dingwall .1999. "The Marginalization of Domestic Violence in Divorce Mediation,” 13 International Journal of Law, Policy and the Family: 174-190.

Hand, Keith J. 2011. "Resolving Constitutional Disputes in Contemporary China," University of Pennsylvania East Asia Law Review 7(1): 51-159.

He, Xin. 2009. "Routinization of Divorce Practice in China: Institutional Constraints' Influence on Judicial Behavior," International Journal of Law, Policy and the Family 23: 83-109.

He, Xin and Kwai Hang Ng 2012 manuscript. "Internal Contradictions of Judicial Mediation.”

----.2013 forthcoming. "Pragmatic Discourse and Gender Inequality in China," Law \& Society Review.

Hester, M., Pearson, C. and Radford, L. 1997. Domestic Violence: A National Survey of Court Welfare and Voluntary Sector Mediation Practice. Bristol: Policy Press. 
Huang, Philip C. 2010. Chinese CivilJustice, Past and Present. Lanham, Md.: Rowman \& Littlefield Publishers.

Jiao, Xiaoyang. 2008. "Call for legislation on domestic violence" China Daily (web edition) at http://www.chinadaily.com.cn/china/2008npc/2008-03/13/content_6532473.htm, last visited June 1, 2002.

Liu, Donghua. 2001. "Five-Year Consulting Report.” Center for Women’s Law Studies and Legal Service of Peking University.

Lubman, Stanley. 1999. "Dispute Resolution in China After Deng Xiaoping: Mao and Mediation Revisited,” 11 Columbia Journal of Asian Law 2.

Mather, Lynn, and Barbara Yngvesson. 1980-81. "Language, Audience, and the Transformation of Disputes," Law and Society Review 15:775-821.

Merry, Sally Engle. 2006. Human Rights \& Gender Violence, Chicago: The University of Chicago Press.

Minzner, Carl. 2011. "China's Turn against Law," American Journal of Comparative Law 59 (4): 935-984.

Peerenboom, Randall. 2002. China’s Long March toward Rule of Law. New York: Cambridge University Press.

Peng, Shizhong. 2011. "Nengdong sifa shiyexia minshi tiaojie gaige de jingxiang xuanze [Paths of the Civil Mediation Reform from Judicial Activism Perspectivel," Jinan xuebao (zhexue shehui kexue ban) [Journal of Jinan University (Philosophy and Social Sciences)] 1:52-58.

Rifkin, Janet. 1984. "Mediation from a Feminist Perspective: Promise and Problems," Law and Inequality 2(1): 21.

Robyn Wexler, Domestic Violence, Not Just a Family Affair, CHINA DEVELOPMENT BRIEF, at http://www.chinadevelopmentbrief.com/article.asp?art=207 (last visited April 19, 2003).

Silbey, Susan S. and Sally E. Merry. 1986 "Mediator Settlement Strategies," Law and Policy 8(1): 732.

Trinder, Liz, Alan Firth, and Christopher Jenks. 2010. "'So Presumably Things have Moved on Since Then?' The Management of Risk Allegations in Child Contact Dispute Resolution.” International Journal of Law, Policy and the Family 24(1): 29-53.

Wang, Liming. 2009. “Characteristics of China's Judicial Mediation System,” Asia Pacific Law Review 17 (Special Issue on Mediation): 67.

Wang, Xingjuan. 2004. “Domestic Violence in China.” In Holding up Half the Sky: Chinese 
Women Past, Present, and Future, edited by Tao Jie, Zheng Bijun, and Shirley L. Mow. New York: Feminist Press at the City University of New York.

Waye, Vicki and Ping Xiong. 2011. "The Relationship between Mediation and Judicial Proceedings in China," Asian Journal of Comparative Law 6(1): 2.

Woo, Margaret .2003. "Shaping Citizenship: Chinese Family Law and Women,” 15 Yale J. Law \& Feminism 99-134.

Wu, Ruozhi (2007) [当代中国家事法制实践研究一以华南R县为例] (On the Practice of the Family Law System in Contemporary China-South China's R County as an Example). Ph.D. Dissertation, Renmin University of China.

Wu, Zhi. 2009. "Litigation Mediation for Intellectual Property Disputes in Chinese Local Courts: Experiences and Contradictions," 17 Asia Pac. L. Rev. 117-131.

Xinhua News Agency. 2009. "Domestic Violence Increases in China,” at http://www.chinadaily.com.cn/china/2009-03/07/content_7551147.htm (last visited June 1, 2012).

Xu, Xin. 2006a. Jiufen jiejue yu shehui hexie [Dispute Resolution and Social Harmony]. Beijing: Law Press.

Xu, Xin. 2006b. “Why Do the Judges Not Trust Witnesses?” (法官为什么不相信证人), Peking University Law Journal (中外法学) 2006, No. 3, 347.

Zhong, Jianhua and Yu Guanghua 2004. "Establishing the Truth on Facts: Has the Chinese Civil Process Achieved This Goal?” Journal of Transnational Law and Policy 13: 393-443.

Zhu, Suli. 2010. "Guanyu nengdong sifa yu datiaojie [On Judicial Activism and Grand Mediation]," Zhongguo faxue [China Legal Science] 1: 14.

\section{Statutes Cited:}

The Marriage Law of the PRC, issued on September 10, 1980; amended on April 28, 2001. 